\title{
Prevalence of hepatitis $G$ virus in liver disease
}

\author{
Hitoshi Takagi MD PhD, Satoru Kakizaki MD PhD, Ken Satoh MD PhD, Mitsuo Toyoda MD, Norio Horiguchi MD, \\ Hisashi Takayama MD PhD, Daisuke Kanda MD PhD, Hiroaki Nakajima MD, Takeshi Ichikawa MD, Akira Kojima MD, \\ Yutaka Matsuzaki MD PhD, Ryuya Shimoda MD, Tatsuhiko Matsumoto MD, Mieko Kaneko MD, Yoshiaki Hashimoto MD, \\ Takehiko Abe MD PhD, Takeaki Nagamine MD PhD, Masatomo Mori MD PhD
}

H Takagi, S Kakizaki, K Satoh, et al. Prevalence of hepatitis G virus in liver disease. Can J Gastroenterol 1999;13(10):823826. The prevalence of hepatitis $\mathrm{G}$ virus (HGV) in liver disease of non- $A,-B,-C$ viral hepatitis, hepatitis $B$ and hepatitis $C$ was determined. Two of 44 patients $(4.5 \%)$ with liver injury without any hepatitis $\mathrm{A}, \mathrm{B}$ or $\mathrm{C}$ marker were positive for $\mathrm{HGV}$. One of five cases of hepatocellular carcinoma was positive for HGV. One of three cases with fulminant hepatitis was positive for HGV. This case was negative at the onset of fulminant hepatitis and became positive after plasmapheresis. No patient with acute $(n=8)$ or chronic $(n=5)$ hepatitis or liver cirrhosis $(n=8)$ was positive for $\mathrm{HGV}$ in non-A, - B, -C liver disease. One of 30 patients with various HBV-positive liver diseases and nine (17.3) of 52 patients with type $\mathrm{C}$ liver disease were positive for $\mathrm{HGV}$. In patients with hepatitis C, four (28.6\%) of $14 \mathrm{HGV}$-co-infected patients were complicated with diabetes mellitus compared with four $(10.5 \%)$ of 38 single hepatitis $\mathrm{C}$ virus (HCV)-infected patients (not significant). In $12 \mathrm{HGV}$-positive patients, eight of 10 (80\%) had a history of blood transfusion. In HCV-positive patients, co-infection with $\mathrm{HGV}$ was not a risk factor in patients with diabetes mellitus as a complication. HGV appeared to cause non- A, - B, -Chepatitis rarely, and its main route of infection was blood transfusion.

Key Words: Diabetes mellitus; Hepatitis G virus; Hepatocellular carcinoma; Non-A, non-B hepatitis

\section{Prévalence du virus de l'hépatite $G$ dans la maladie hépatique}

RÉSUMÉ : La prévalence du virus de l'hépatite G (HGV) dans la maladie hépatique liée à l'hépatite virale non $\mathrm{A}$, non $\mathrm{B}$, non $\mathrm{C}$, dans l'hépatite $\mathrm{B}$ et dans l'hépatite C, a été déterminée. Deux patients sur 44 (4,5\%) présentant une atteinte hépatique sans marqueur de l'hépatite $A$, B ou C se sont révélés positifs à l'égard du HGV. Un cas d'hépatocarcinome s'est révélé positif à l'égard du HGV, un cas d'hépatite fulminante sur trois s'est révélé positif à l'égard du HGV. Ce cas était négatif lors du déclenchement de l'hépatite fulminante et est devenu positif après la plasmaphérèse. Aucun patient atteint d'hépatite aiguë $(n=8)$ ou chronique $(n=5)$ ou de cirrhose hépatique $(\mathrm{n}=8)$ n'était positif à l'égard du HGV dans la maladie non $\mathrm{A}$, non $\mathrm{B}$ et non $\mathrm{C}$. Un patient sur 30 atteints de diverses maladies hépatiques HBV-positives et neuf (17,3\%) patients sur 52 atteints d'une maladie hépatique de type C se sont révélés positifs à l'égard du HGV. Chez les patients atteints de l'hépatite C, quatre (28,6 \%) sur 14 patients co-infectés par le HGV présentaient concomitamment un diabète sucré, contre quatre patients $(10,5 \%)$ sur 38 infectés par le virus de l'hépatite C seulement (non significatif). Chez 12 patients HGV-positifs, 8 sur 10 (80 $\%)$ avaient déjà reçu des transfusions sanguines. Pour les patients HCV-positifs, la co-infection par le HGV n'a pas été jugée un facteur de risque chez les patients présentant un diabète sucré comme complication. L'HGV a semblé rarement en cause dans l'hépatite non A, non B, non Cet sa principale voie de transmission a été la transfusion sanguine.
$\mathrm{H}_{\mathrm{i}}^{\mathrm{e}}$ epatitis $\mathrm{G}$ virus (HGV) was discovered by two groups independently (1-4) and was designated as hepatitis GB virus C (HGBV-C) (1-3) and HGV (4). At first, these were considered to be different agents, but because of their high sequence homology they are now considered to be the same virus (5). Screening of HGBV-C/HGV by polymerase chain reaction (PCR) revealed the positive rate to be $1.6 \%$ in the general population in the United States (4), 3.1\% in patients on hemodialysis in Japan (6) and 50\% in those with non- $A,-B,-C$ fulminant hepatitis in Japan (7). Furthermore, HGBV-C/HGV is reported to be transmitted through blood transfusion, and co-infection with HCV is frequently found $(4,8)$. Although data relating to HGV have accumulated, prevalence of HGV infection in Japan is not yet known, nor is its virulence and complications. We report the frequency of $\mathrm{HGV}$ in patients with various liver diseases

The First Department of Internal Medicine, Gunma University School of Medicine, Gunma, Japan

Correspondence and reprints: 3-39 Showamachi Maebashi Gunma 371-8511, Japan. Telephone +81-272-20-8127, fax +81-272-20-8136, email htakagi@sb.gunma-u.ac.jp

Received for publication July 2, 1998. Accepted November 30, 1998 
TABLE 1

Frequency of hepatitis G virus (HGV) in non-A, -B and -C hepatitis (NANBC) in Gunma, Japan

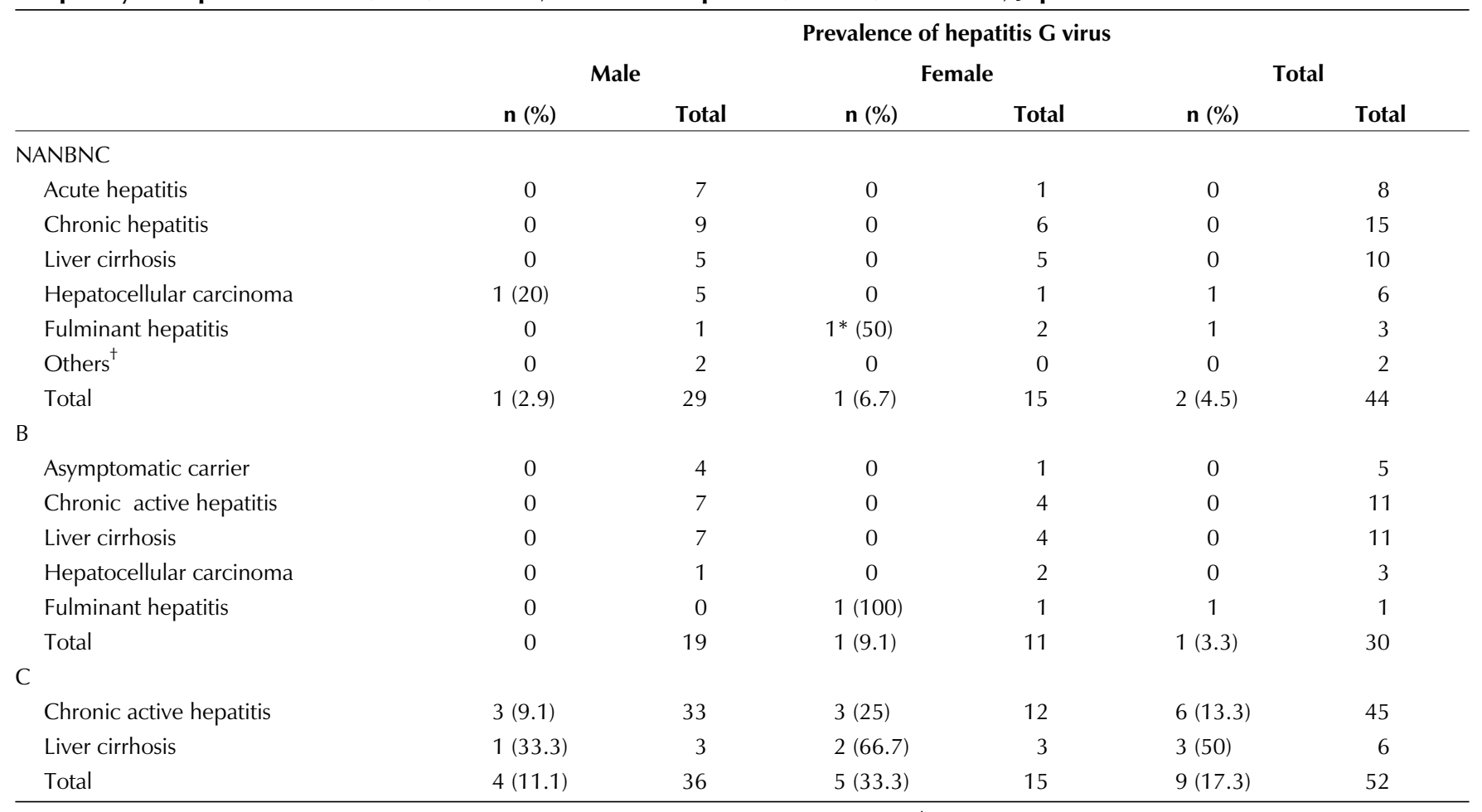

*At the onset before plasmapheresis (-), and after plasmapheresis and liver transplantation(+); ${ }^{\dagger}$ Granulomatous hepatitis, nonspecific reactive hepatitis

with hepatitis B virus (HBV), hepatitis $\mathrm{C}$ virus (HCV) and without any hepatitis A virus (HAV), HBV or HCV marker in Japan and discuss the complications.

\section{PATIENTS AND METHODS}

Eighty-four male and 41 female adults, a total of 125 patients, with liver dysfunction were enrolled in the study and screened for serum HGV. Forty-four patients with elevated serum alanine aminotransferase and aspartate aminotransferase levels without any hepatitis virus marker, including anti-HAV immunoglobulin $\mathrm{M}$, hepatitis B surface antigen (HBsAg), anti-hepatitis B core immunoglobulin $\mathrm{M}$, HBV-DNA and anti-HCV antibody, were designated as having non- $A$, non- $B$, non-C (NANBNC) hepatitis. Autoimmune hepatitis was diagnosed by criteria described elsewhere (9). Ultrasonography disclosed fatty liver, and histological diagnosis was obtained by liver biopsy in almost all the cases. Thirty patients with positive $\mathrm{Hbs} \mathrm{Ag}$ and 52 patients with positive anti-HCV antibody were screened for HGV. Determination of HGV RNA by reverse transcriptase PCR has been reported previously (6). Briefly, the primers subjected to the first round PCR were as follows: 5'TCYTTGATGATD GAACTGTC3' (Y=T or C and D=A, G or T), 5'TATGGG CATGGHATHCCYCT3'. The nested primers for the second round of PCR were $5^{\prime} \mathrm{CATTCVAAGGCGGAGTGY}$ GA3', in which $V=A, C$ or $G$ and 5'TCYTTACCCCTRTA ATAGGC3', in which $\mathrm{R}=\mathrm{A}$ or $\mathrm{G}$. The expected size of the products of the first and second round PCR were 158 and 83 base pairs, respectively.

\section{RESULTS}

Prevalence of $\mathrm{HGV}$ in patients with non-A, $-\mathrm{B},-\mathrm{C}$ hepatitis, type $B$ hepatitis and type $C$ hepatitis: $H G V$ was not detected among eight cases of acute hepatitis, 15 cases of chronic hepatitis and 10 cases of liver cirrhosis with NANBNC liver disease (Table 1). One male patient of six with hepatocellular carcinoma (HCC) and one female with fulminant hepatitis who had undergone living-related liver transplantation for fulminant hepatitis were positive for HGV. The latter patient was negative for HGV at the onset of fulminant hepatitis and seroconverted after numerous plasmapheresis procedures and the living-related liver transplantation. Therefore, HGV infection was thought to occur after the onset of fulminant hepatitis and was not the causal virus of fulminant hepatitis in this case. Three cases of fulminant hepatitis, including this case were not positive for HGV at the onset of the disease. A male patient with granulomatous hepatitis and a second male with nonspecific reactive hepatitis were negative for $\mathrm{HGV}$. Two of 44 patients (4.5\%) with NANBNC hepatic injury had positive HGV findings.

Among HBV-positive patients, only one female patient with fulminant hepatic failure was positive for HGV after several courses of plasmapheresis. None of the asymptomatic carriers or patients with acute hepatitis, chronic active hepatitis, liver cirrhosis or hepatocellular carcinoma were positive for $\mathrm{HGV}$ in this group.

Among HCV-positive patients, six of 45 (13.3\%) with chronic active hepatitis and three of six $(50 \%)$ with liver cir- 
TABLE 2

Characteristics of 12 hepatitis G virus (HGV)-positive patients

\begin{tabular}{|c|c|c|c|c|c|c|}
\hline Patient & Age & Sex & Disease & Hepatitis virus & $\begin{array}{l}\text { Blood transfusion } \\
\text { before HGV detection }\end{array}$ & Other complications \\
\hline 1 & 18 & $\mathrm{~F}$ & Late onset hepatic failure & - & + & $\begin{array}{l}\text { After multiple plasmapheresis, LRLT from } \\
\text { her mother was performed. Three years } \\
\text { after LRLT, the patient developed } \\
\text { cirrhosis of the transplanted liver }\end{array}$ \\
\hline 2 & 65 & M & Hepatocellular carcinoma & - & + & $\begin{array}{c}\text { Complicated with malignant fibrous } \\
\text { histiocytoma }\end{array}$ \\
\hline 4 & 40 & $\mathrm{~F}$ & Chronic active hepatitis & $\mathrm{C}$ & + & \\
\hline 5 & 60 & $\mathrm{~F}$ & Liver cirrhosis & $\mathrm{C}$ & + & Diabetes mellitus \\
\hline 6 & 27 & $\mathrm{~F}$ & Chronic persistent hepatitis & $\mathrm{C}$ & - & \\
\hline 7 & 65 & $\mathrm{~F}$ & Chronic active hepatitis & $\mathrm{C}$ & - & \\
\hline 8 & 69 & $\mathrm{~F}$ & Liver cirrhosis & $\mathrm{C}$ & + & \\
\hline
\end{tabular}

F Female; LRLT Living related liver transplantation; M Male

TABLE 3

Prevalence of hepatitis $G$ virus in patients with and without diabetes mellitus (DM) or hepatitis B and C or non-B, non-C hepatitis

\begin{tabular}{|c|c|c|c|c|c|c|c|}
\hline \multirow[b]{2}{*}{ Hepatitis virus } & \multirow[b]{2}{*}{ DM } & \multicolumn{6}{|c|}{ Prevalence of hepatitis G virus } \\
\hline & & Male, n (\%) & Total & Female, n (\%) & Total & Total, n (\%) & Total \\
\hline B & - & 0 & 17 & $1(9.1)$ & 11 & $1(3.4)$ & 28 \\
\hline \multirow[t]{2}{*}{$\mathrm{C}$} & - & $3(11.1)$ & 27 & $1(9.1)$ & 11 & $4(10.5)$ & 38 \\
\hline & + & $1(11.1)$ & 9 & $3(60)$ & 5 & $4(28.6)$ & 14 \\
\hline None & + & 0 & 15 & 0 & 15 & 0 & 30 \\
\hline
\end{tabular}

rhosis were positive for HGV. Nine of 52 (17.3\%) $\mathrm{HCV}$-positive patients with chronic active hepatitis and liver cirrhosis were positive for HGV. There were no significant differences in age among these three groups.

Detail of $\mathrm{HGV}$-positive cases and relation to diabetes mellitus: Twelve patients with liver disease had positive HGV results (Table 2 ). Two had no hepatitis $A, B$ or $C$ virus, one had fulminant hepatitis $\mathrm{B}$ and nine had $\mathrm{HCV}$-positive chronic liver disease. Seven of 12 patients in this group had blood transfusions before the detection of HGV. As a complication in $\mathrm{HGV}$-positive patients, a patient with $\mathrm{HCC}$ without hepatitis $\mathrm{A}, \mathrm{B}$ or $\mathrm{C}$ virus had malignant fibrous histiocytoma.

One patient with chronic active hepatitis $\mathrm{C}$ and three $\mathrm{HCV}$-positive patients with liver cirrhosis had diabetes mellitus (DM) (Table 3). The incidence of DM was thought to be higher in $\mathrm{HCV}$-positive patients who were also HGVpositive; therefore, all $\mathrm{HBV}$ - and $\mathrm{HCV}$-positive patients with DM were analyzed for their HGV status. Consequently, one of the HBV-positive patients with DM was negative for $\mathrm{HGV}$, and four of 38 (10.5\%) non-DM patients and four of
14 (28.6\%) DM patients were HGV-positive. In HCV-positive patients complicated with DM, the HGV-positive rate tended to be higher, but the difference was not significant. The patients with DM tended to be older than those without DM, but no statistical significance was demonstrated.

\section{DISCUSSION}

Many aspects of HGV have not been elucidated. Recent reports have described $\mathrm{HGV}$-positive rates of $0.8 \%$ (5) and $1.7 \%$ (4) in the general populations of Japan and the United States, respectively. We detected only HGV positivity in two patients of 41 with NANBNC liver disease (4.9\%), one of 30 HBV-positive patients (3.3\%) and nine of $52 \mathrm{HCV}$-positive patients $(17.6 \%)$. In the case of NANBNC liver disease, this number is comparable with reports for acute non- $A,-B,-C$, $-\mathrm{D},-\mathrm{E}$ hepatitis $(2 \%)$ and chronic non-A, $-\mathrm{B},-\mathrm{C},-\mathrm{D},-\mathrm{E}$ hepatitis (4\%) in Japan (10), but another group from Japan (11) described a $7.1 \%$ positivity rate in NANBNC hepatitis, which was lower than that in Pakistan in patients with NANBNC chronic active hepatitis (12\%) (12).

The high co-incidence of $\mathrm{HCV}$ and $\mathrm{HGV}(4,7)$ in 
blood-transfused patients suggests that HGV may be a blood-borne pathogen, as are HCV and HBV. Study of the clinical importance of HGV focuses on the degree of its virulence on the liver, its role as a cause of acute or chronic hepatitis and hepatocarcinogenesis. As for the virulence of HGV in the liver, Yoshiba et al (7) first reported that HGV could induce fulminant hepatitis. On the other hand, Alter et al (13) reported that about $65 \%$ of patients $\mathrm{HGV}$-infected by blood transfusion had no evidence of liver dysfunction, and only $5 \%$ developed post-transfusion hepatitis, indicating that the virulence of $\mathrm{HGV}$ is mild or nonexistent. Another report also supports low virulence of HGV (14). Tanaka et al (8) reported two cases of chronic hepatitis, one of liver cirrhosis and one of HCC among 25 patients with NANBNC hepatitis. Accumulating data suggest that HGV might cause chronic infection but that the progression of any hepatitis that may be caused by HGV is very slow $(12,14)$. This is compatible with the reports by Alter et al (15), who demonstrated no causal relation between HGV and hepatitis. Hepatocarcinogenesis by HGV is also under controversy. Although most reports demonstrated that HGV does not cause HCC $(13,14)$, HCC in patients with HGV but without HBV and HCV occurs in a small percentage of such pa-

\section{REFERENCES}

1. Simons JN, Pilot-Matias TJ, Leary TP, et al. Identification of two flavivirus-like genomes in the GB hepatitis agent. Proc Natl Acad Sci USA 1995;92:3401-5.

2. Simons JN, Leary TP, Dawson GJ, et al. Isolation of novel virus-like sequence associated with human hepatitis. Nat Med 1995; 1:564-9.

3. Leary TP, Muerhoff AS, Simons JN, et al. Sequence and genomic organization of GBV-C: a novel member of the flaviviridae associated with human non-A-E hepatitis. J Med Virol 1996;48:60-7.

4. Linnen J, Wages J Jr, Zhang-Keck ZY, et al. Molecular cloning and disease association of hepatitis $G$ virus: a transfusion-transmissible agent. Science 1996;271:505-8.

5. Hayashi J, Furusyo N, Sawayama Y, et al. Hepatitis G virus in the general population and in patients on hemodialysis. Dig Dis Sci 1998;43:2143-8.

6. Masuko K, Mitsui T, Iwano K, et al. Infection with hepatitis GB virus $\mathrm{C}$ in patients on maintenance hemodialysis. N Engl J Med 1996;334:1485-90.

7. Yoshiba M, Okamoto H, Mishiro S. Detection of the GBV-C hepatitis virus genome in serum from patients with fulminant hepatitis of unknown etiology. Lancet 1995;346:1131-2.

8. Tanaka E, Nakatsuji Y, Uemura K, Kiyosawa K. [Hepatitis G virus infection and hepatitis G]. Kan Tan Sui 1996;32:801-6.

9. Johnson PJ, McFarlene IG. Meeting report: International Autoimmune Hepatitis Group. Hepatology 1993;18:998-1005. tients (16). We found only one HGV-infected patient among five patients with NANBNC HCC (20\%). The patient's disease was complicated with fibrous histiocytoma as a double cancer. Double cancer with HCC has been discussed in viral, immunological aspects and blood transfusion (17). HGV seemed to have another possibility for carcinogenesis not only in the liver but also in other organs such as soft tissues such as muscle or subcutaneous tissue.

Further investigation is needed to clarify the relationship between HGV and HCC, such as anti-HGV staining in the liver if the antibody to HGV were to become available.

\section{CONCLUSIONS}

HGV can be transmitted through blood transfusion and may be the cause of mild hepatic injury, but the chronic progression by HGV, such as by HCV, through chronic active hepatitis to liver cirrhosis to HCC is thought to be quite rare.

ACKNOWLEDGEMENT: We are indebted to Professor Tadashi Mayumi and Dr Hiroaki Okamoto in Immunology Division, Jichi Medical School, Tochigi, Japan for the assay of HGV.

10. Moriyama M, Miyauchi I, Nakai K, et al. HGV infection in Japanese patients with various forms of liver disease. Hepatology 1996;24(Suppl):550A. (Abst)

11. Nakatsuji Y, Shih JWK, Tanaka E, et al. Prevalence and disease association of hepatitis $G$ virus infection in Japan. J Viral Hepat 1996;3:307-16.

12. Alter MJ, Gallagher M, Morris TT, et al. Role of hepatitis G virus in the etiology and clinical course of viral hepatitis. Hepatology 1996;24(Suppl):247A. (Abst)

13. Alter HJ, Nakatsuji Y Shih JWK, et al. Transfusion-associated hepatitis G virus: infection. IX Triennial International Symposium on Viral Hepatitis and Liver Disease, Rome, April 21-25, 1996:120. (Abst)

14. Karayiannis P, Hadziyannis SJ, Kim J, et al. Hepatitis G virus infection: clinical characteristics and response to interferon. J Viral Hepat 1997;4:37-44.

15. Alter HJ, Nakatsuji Y, Melpolder J, et al. The incidence of transfusion-associated hepatitis $\mathrm{G}$ virus infection and its relation to liver disease. N Engl J Med 1997;336:747-54.

16. Moriyama M, Miyauchi I, Nakai K, et al. HGV infection in Japanese patients with various forms of liver disease. Hepatology 1996;24(Suppl):550A. (Abst)

17. Kakizaki S, Yamada T, Takagi, H, et al. Hepatocellular carcinoma with extrahepatic primary malignant neoplasms. Int J Clin Oncol 1998,3;203-8. 


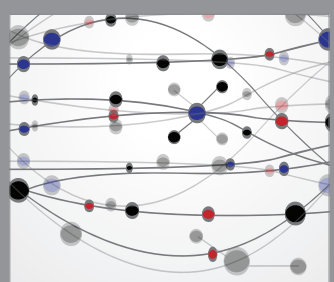

The Scientific World Journal
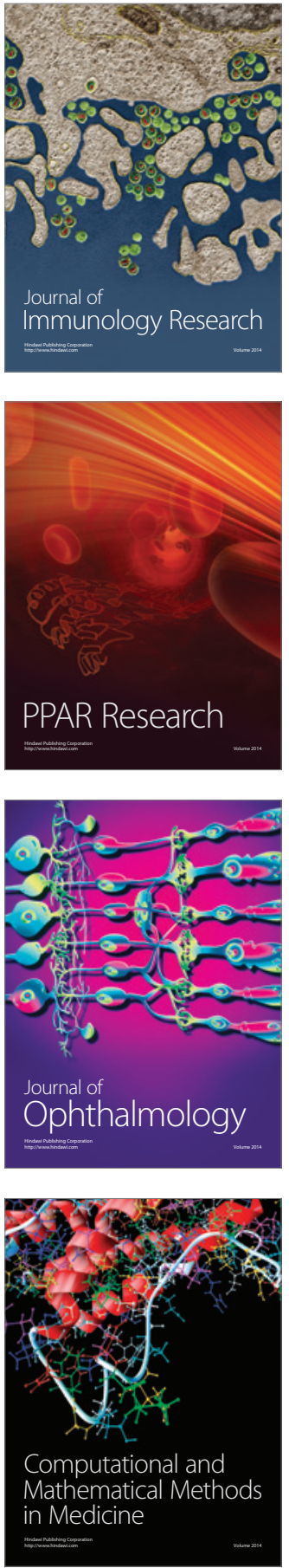

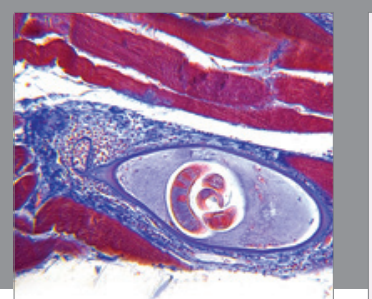

Gastroenterology Research and Practice

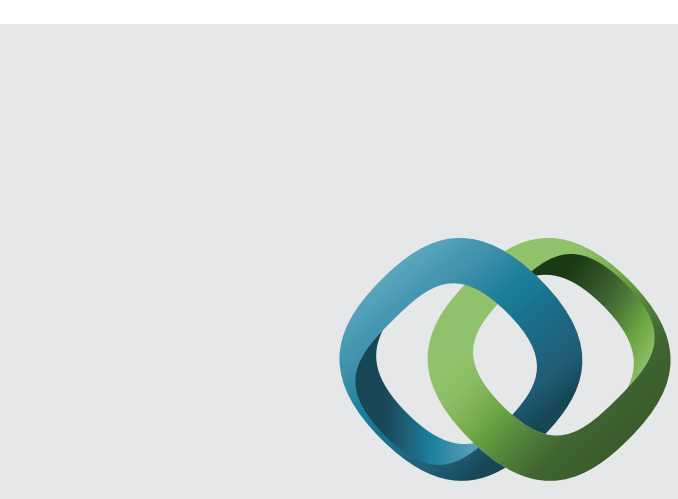

\section{Hindawi}

Submit your manuscripts at

http://www.hindawi.com
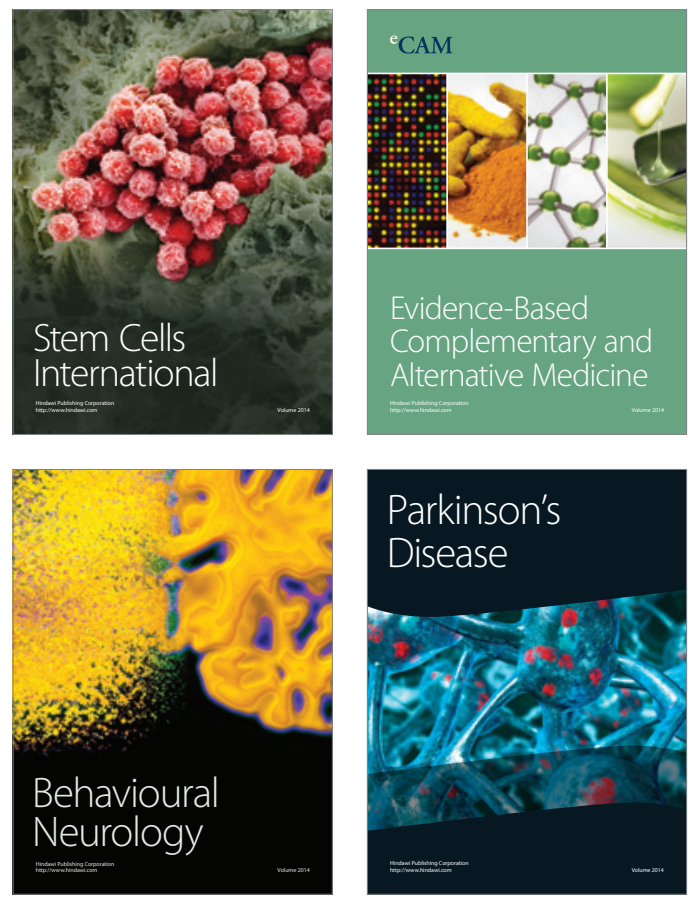
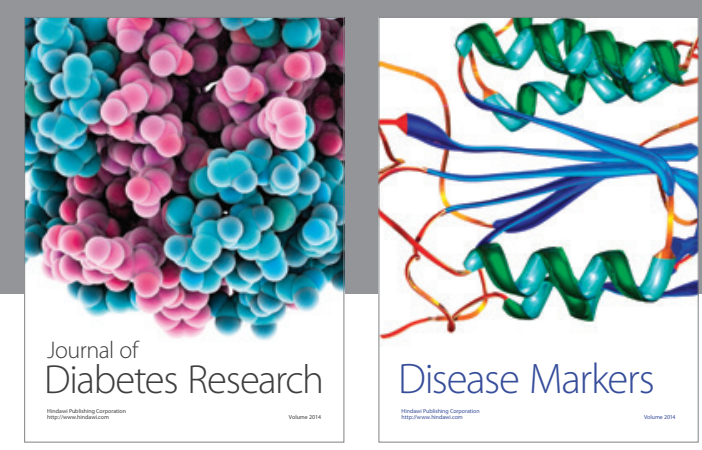

Disease Markers
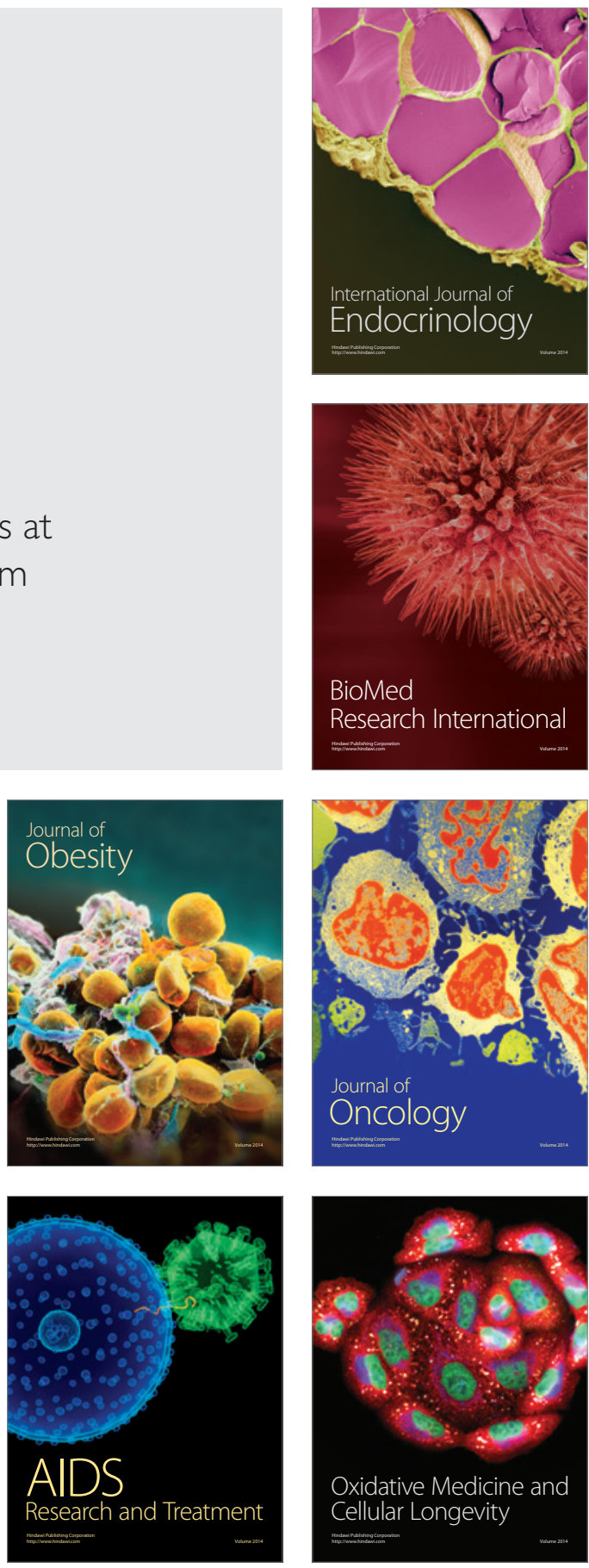